\title{
Mechanisms of cardiovascular regulation in male rabbits chronically exposed to cadmium
}

\author{
P BOSCOLO, ${ }^{1}$ M CARMIGNANI ${ }^{2}$
}

\begin{abstract}
From the Institute of Human Pathology and Social Medicine, ${ }^{1}$ University of Chieti, and Institute of Occupational Medicine, ${ }^{1}$ Catholic University School of Medicine, Rome, and from the Institute of General Biology, ${ }^{2}$ University of L'Aquila, and Institute of Pharmacology, ${ }^{2}$ Catholic University School of Medicine, Rome, Italy
\end{abstract}

ABSTRACT Male rabbits received $20 \mu \mathrm{g} / \mathrm{ml}$ of cadmium in drinking water for nine months. At the end of the treatment aortic vascular resistance was increased, whereas maximum rate of increase in left ventricular pressure, aortic blood flow, stroke volume, cardiac output, left ventricular minute work, and left ventricular stroke work were reduced. Arterial blood pressure, heart rate, and the index of myocardial oxygen consumption were not modified. The exposed rabbits also showed reduced pressor responses to vagotomy, increased cardiovascular responses to angiotensin I and II and isoprenaline, and lower responses to serotonin and guanethidine; the bradycardia induced by clonidine was augmented; the cardiovascular effects of bilateral carotid occlusion, hexamethonium, phenylephrine, histamine, acetylcholine, tyramine, papaverine and verapamil were unaltered. In the treated rabbits cadmium was appreciably higher in the kidney than in the heart; however, renal concentrations of cadmium were lower than those reported as critical for workers exposed to cadmium. Zinc was increased in the kidney but not in the heart, whereas copper remained unchanged in the examined organs. In rabbits treated with cadmium the increased aortic vascular resistance and the reduced myocardial contracility contribute to preserve a haemodynamic equilibrium without alteration of blood pressure and heart rate; the question of whether a similar condition may be present in people exposed to cadmium with normal caradiovascular parameters is discussed.

Exposure to cadmium has been found to affect renal function both in workers ${ }^{1}$ and in the general population ${ }^{2}$ and a relation between cadmium concentrations in the liver and heart disease has been reported. ${ }^{3}$ An increased mortality from cardiovascular disorders was observed in a population with low molecular weight proteinuria living in a cadmium polluted area. ${ }^{4}$ On the other hand, there are controversial data on the role of cadmium in inducing hypertension. ${ }^{156}$ It seems likely that in the development of hypertension in man the effects of the concomitant exposure to several elements and interactions with other variables may play a significant part. $^{7}$

In a previous study we discussed the mechanisms by which chronic cadmium exposure may affect the cardiovascular system. ${ }^{8}$ In that study of chronically Cd exposed male rats we found evidence for arterial

Accepted 3 February 1986 hypertension, increased cardiac inotropism, reduced heart rate (in the group treated with the lower dose), and an altered vascular response to noradrenaline, adrenaline, angiotensin I, and bradykinin. Moreover, in other investigations we showed in male, but not in female, Sprague-Dawley rats exposed to cadmium an arterial hypertension negatively correlated with the urinary kallikrein excretion. ${ }^{910}$ The $\mathrm{Cd}$ induced hypertension observed in these studies was related to an increase of stroke volume or peripheral resistance, or both, whereas the bradycardia was related to an activation of the afferent baroflex pathways or to a depression of the excitability of the sinoatrial node through a direct effect or both.

The present study was performed to evaluate in chronically cadmium exposed rabbits some mechanisms regulating cardiovascular homeostasis. The purpose was to obtain further data which may be useful in explaining the haemodynamic effects of cadmium in man. 


\section{Materials and methods}

Sixteen New Zealand three month old male rabbits, randomly divided into two groups of eight animals, were fed a standard laboratory diet. One group received $20 \mu \mathrm{g} / \mathrm{ml}$ of cadmium (as $\mathrm{CdCl}_{2}$ ) in deionised drinking water for nine months, while the other group was kept as a control. At the end of the treatment, the rabbits were anaesthetised with sodium pentothal, initially administered as a single intravenous injection of $45 \mathrm{mg} / \mathrm{kg}$ body weight; they were then injected periodically with an intravenous dose of $15 \mathrm{mg} / \mathrm{kg}$ of the same anaesthetic to maintain a stable anaesthesia during the assessment of the cardiovascular function. The trachea was cannulated to allow spontaneous breathing. Afterwards, the animals were killed by bleeding and organs were taken for histological examination and the determination of cadmium, zinc, and copper concentrations.

\section{HAEMODYNAMIC MEASUREMENTS}

Polyethylene catheters were inserted: $(a)$ into the aorta through the right femoral artery in order to measure blood pressure (BP), $(b)$ into the left ventricle through the left common carotid artery for recording the maximum rate of increase in left ventricular pressure (dLVP/dt), and (c) into the left jugular vein for drug administration. The catheters contained sodium heparin (100 USP/ml). BP (systolic and diastolic or mean) was continuously monitored with a P23Db Statham pressure transducer (Statham Medical Instruments, Los Angeles, Calif), connected with a Beckman RM dynograph recorder (Beckman Instruments, Inc, Schiller Park, III), and averaged electronically. To assess cardiac inotropism, dLVP/dt was determined using a Biotronex BL 620 derivative computer (Biotronex Laboratories, Inc, Kensington, Mass) according to Neal et al, ${ }^{11}$ Crawford et al, ${ }^{12}$ and Davidson et al. ${ }^{13}$ Heart rate (HR) was determined by a Beckman cardiotachometer coupler triggered by the R-peak of the lead II electrocardiogram. An electromagnetic flow probe $(2-3 \mathrm{~mm}$ inside diameter) was implanted in the abdominal aorta, as previously described, ${ }^{14}$ to measure the blood flow (ABF; systolic and diastolic or mean) using a Statham flowmeter SP 2202. Stroke volume (SV) was obtained by integrating the pulsatile $\mathrm{ABF}\left(\int \mathrm{ABF}_{\mathrm{dt}}\right)$ using a Biotronex apparatus (model BL 622). Together with BP, dLVP/dt, HR, ABF, and SV were also continuously monitored. Cardiac output (CO), aortic vascular resistance (AVR), index of myocardial \& oxygen consumption (MOC), left ventricular minute work (LVMW), and stroke work (SW) were calculated (table 1).

\section{STUDY OF CARDIOVASCULAR FUNCTION}

The cardiac and vascular parameters were determined in basal conditions, at least 30 minutes after completion of the surgical procedures. Bilateral carotid occlusion (BCO) of the common carotid arteries was then performed for a period of 30 seconds. ${ }^{8-14}$ This was followed by bilateral selective vagotomy, carried out at the neck below the nodose ganglion. Afterwards, receptor stimulating drugs were injected intravenously: phenylephrine $(20 \mu \mathrm{g} / \mathrm{kg})$, isoprenaline $(0.3 \mu \mathrm{g} / \mathrm{kg})$, angiotensin I $(0.25 \mu \mathrm{g} / \mathrm{kg})$ and II $(0.25$ $\mu \mathrm{g} / \mathrm{kg})$, histamine $(5 \mu \mathrm{g} / \mathrm{kg})$, serotonin $(10 \mu \mathrm{g} / \mathrm{kg})$ and acetylcholine $(2.5 \mu \mathrm{g} / \mathrm{kg})$, tyramine $(1 \mathrm{mg} / \mathrm{kg})$, hexamethonium $(2.5 \mathrm{mg} / \mathrm{kg})$, clonidine $(20 \mu \mathrm{g} / \mathrm{kg}$, b intracarotid infusion), guanethidine $(0.5 \mathrm{mg} / \mathrm{kg})$ papaverine $(1 \mathrm{mg} / \mathrm{kg})$, and verapamil $(50 \mu \mathrm{g} / \mathrm{kg})$ wer administered successively. All drugs were dissolved in $0.9 \%$ saline solution. The doses were expressed in terms of free bases and peak measures were considered. The administration of the solvent alone did not induce significant cardiovascular modification. Each consecutive test was performed only when all parameters had spontaneously returned to the values preceding the injection of phenylephrine and remained stable. The other general procedures have been described. ${ }^{8-14}$

Table 1 Parameters, calculations, and units of measurement to determine in vivo cardiac function and systemic haemodynamics

\begin{tabular}{|c|c|c|}
\hline Parameters & Calculation & Units \\
\hline $\begin{array}{l}\text { Systolic aortic blood pressure (SBP) } \\
\text { Diastolic aortic blood pressure (DBP) } \\
\text { Mean aortic blood pressure (MBP) } \\
\text { Maximum rate of increase in left ventricular pressure (dLVP/dt) } \\
\text { Heart rate (HR) } \\
\text { Aortic blood flow (ABF) } \\
\text { Stroke volume (SV) } \\
\text { Cardiac output (CO) } \\
\text { Aortic vascular resistance (AVR) } \\
\text { Index of myocardial oxygen consumption (MOC) } \\
\text { Left ventricular minute work (LVMW)* } \\
\text { Left ventricular stroke work (SW)* }\end{array}$ & $\begin{array}{l}\text { Measured } \\
\text { Measured } \\
\text { SBP }+2 \mathrm{DBP} / 3 \\
\text { Measured } \\
\text { Measured } \\
\text { Measured } \\
\text { Measured }\left(\int_{\mathrm{ABF}} \times 10^{3}\right) \\
\mathrm{SV} \times \mathrm{HR} \times 10^{-3} \mathrm{MB} / \mathrm{mean} \mathrm{ABF} \times 79.9 \\
\mathrm{MBP} / \mathrm{SBP} \times 10^{-3} \\
\mathrm{HR} \times \mathrm{SBP} \times \mathrm{CO} \times 6.8 \\
\text { MBP } \times \mathrm{LVMW} / \mathrm{HR}\end{array}$ & $\begin{array}{l}\mathrm{mm} \mathrm{Hg} \\
\mathrm{mm} \mathrm{Hg} \\
\mathrm{mm} \mathrm{Hg} \\
\mathrm{mm} \mathrm{Hg} / \mathrm{sec} \\
\text { Beats } / \mathrm{min} \\
\mathrm{ml} / \mathrm{min} \\
\mu \mathrm{b} / \mathrm{beat} \\
\mathrm{ml} / \mathrm{min} \\
\mathrm{Dynes} \times \mathrm{sec} \times 10^{-3} / \mathrm{cm}^{-5} \\
\mathrm{~mm} \mathrm{Hg} / \mathrm{beat} / \mathrm{min} \times 10^{-3} \\
\mathrm{kp} \times \mathrm{m} / \mathrm{min} \\
\mathrm{p} \times \mathrm{m} / \mathrm{beat}\end{array}$ \\
\hline
\end{tabular}

"Expressed as "index" (calculated for $5 \mathrm{~kg}$ body weight). 
Table 2 Monitored and derived indices of in vivo cardiac function and systemic haemodynamics in control and cadmium exposed male rabbits*

\begin{tabular}{|c|c|c|}
\hline & Control & Exposed \\
\hline $\begin{array}{l}\text { Systolic aortic blood pressure }(\mathrm{mm} \mathrm{Hg}) \\
\text { Diastolic aortic blood pressure }(\mathrm{mm} \mathrm{Hg}) \\
\text { Mean aortic blood pressure }(\mathrm{mm} \mathrm{Hg}) \\
\text { Maximum rate of increase in left ventricular pressure }(\mathrm{mm} \mathrm{Hg} / \mathrm{sec}) \\
\text { Heart rate (beats/min) } \\
\text { Mean aortic blood flow }(\mathrm{ml} / \mathrm{min}) \\
\text { Stroke volume }(\mu \mathrm{l} / \mathrm{beat}) \\
\text { Cardiac output }(\mathrm{ml} / \mathrm{min}) \\
\text { Aortic vascular resistance }\left(\text { dynes } \times \mathrm{sec} \times 10^{-3} / \mathrm{cm}^{-5}\right) \\
\text { Index of myocardial oxygen consumption }\left(\mathrm{mm} \mathrm{Hg} / \mathrm{beat} / \mathrm{min} \times 10^{-3}\right) \\
\text { Left ventricular minute work }\left(\mathrm{kp} \times \mathrm{m} / \mathrm{min} \times 10^{2}\right) \\
\text { Left ventricular stroke work }\left(\mathrm{p} \times \mathrm{m} / \mathrm{beat} \times 10^{4}\right)\end{array}$ & $\begin{array}{l}105 \pm 6 \\
74 \pm 4 \\
84 \pm 5 \\
2891 \pm 106 \\
163 \pm 6 \\
120 \pm 8 \\
985 \pm 76 \\
157 \pm 11 \\
59 \pm 5 \\
17 \pm 1 \\
9 \pm 1 \\
6 \pm 1\end{array}$ & $\begin{aligned} & 107 \pm 7 \\
& 74 \pm 5 \\
& 85 \pm 6 \\
& 2098 \pm 349 \dagger \\
& 168 \pm 4 \\
& 87 \pm 6 \dagger \\
& 724 \pm 28 \dagger \\
& 122 \pm 6 \dagger \\
& 80 \pm 7 \dagger \\
& 18 \pm 1 \\
& 6 \pm 1 \dagger \\
& 4 \pm 0.5 \dagger\end{aligned}$ \\
\hline
\end{tabular}

*All values are means $\pm \mathrm{SE}$ ( $\mathrm{n}=8$ in both groups).

+Significantly different from control $(p<0.05)$.

Table 3 Cardiovascular changes after bilateral carotid occlusion (BCO), vagotomy, or intravenous administration of several receptor stimulating drugs in control and male rabbits* that had been exposed to cadmium

\begin{tabular}{|c|c|c|c|c|c|c|}
\hline \multirow[b]{3}{*}{$\begin{array}{l}\text { BCO } \\
\text { Vagotomy } \\
\text { Phenylephrine }(20 \mu \mathrm{g} / \mathrm{kg}) \\
\text { Isoprenaline }(0 \cdot 30 \mu \mathrm{g} / \mathrm{kg}) \\
\text { Angiotensin I }(0 \cdot 25 \mu \mathrm{g} / \mathrm{kg}) \\
\text { Angiotensin II }(0 \cdot 25 \mu \mathrm{g} / \mathrm{kg}) \\
\text { Histamine }(5 \mu \mathrm{g} / \mathrm{kg}) \\
\text { Serotonin }(10 \mu \mathrm{g} / \mathrm{kg}) \\
\text { Acetylcholine }(2 \cdot 50 \mu \mathrm{g} / \mathrm{kg})\end{array}$} & \multicolumn{2}{|c|}{ Mean blood pressure } & \multicolumn{2}{|l|}{ Heart rate } & \multicolumn{2}{|l|}{$d L V P / d t \dagger$} \\
\hline & \multicolumn{2}{|c|}{$(\mathrm{mm} \mathrm{Hg})^{-100 \mathrm{~s}}$} & \multicolumn{2}{|c|}{${ }_{(\text {beats } / \mathrm{min})}^{\text {Exposed }}$} & \multicolumn{2}{|c|}{$\begin{array}{c}\text { Control Exposed } \\
\qquad(\mathrm{mm} \mathrm{Hg} / \mathrm{sec})\end{array}$} \\
\hline & $\begin{array}{l}+20 \pm 2 \\
+27 \pm 2 \\
+48 \pm 5 \\
-16 \pm 1 \\
+14 \pm 4 \\
+30 \pm 2 \\
-10 \pm 2 \\
-33 \pm 4 \\
-13 \pm 3\end{array}$ & $\begin{array}{l}+16 \pm 2 \\
+9 \pm 3 \ddagger \\
+52 \pm 6 \\
-30 \pm 2 \ddagger \\
+34 \pm 3 \ddagger \\
+42 \pm 1 \ddagger \\
-12 \pm 3 \\
-15 \pm 4 \ddagger \\
-16 \pm 2\end{array}$ & $\begin{array}{l}+13 \pm 2 \\
+13 \pm 4 \\
-33 \pm 5 \\
+19 \pm 4 \\
-11 \pm 2 \\
-9 \pm 1 \\
-9 \pm 2 \\
-16 \pm 3 \\
-34 \pm 4\end{array}$ & $\begin{array}{l}+14 \pm 2 \\
+13 \pm 3 \\
-39 \pm 9 \\
+21 \pm 4 \\
-12 \pm 2 \\
-33 \pm 8 \ddagger \\
-10 \pm 3 \\
-13 \pm 4 \\
-31 \pm 2\end{array}$ & $\begin{array}{l}+338 \pm 34 \\
+584 \pm 37 \\
-916 \pm 39 \\
+1280 \pm 31 \\
-285 \pm 42 \\
-1382 \pm 28 \\
+604 \pm 47 \\
+1521 \pm 124 \\
-1934 \pm 74\end{array}$ & $\begin{array}{l}+401 \pm 40 \\
+496 \pm 58 \\
-943 \pm 45 \\
+1835 \pm 33 \ddagger \\
-1241 \pm 148 \ddagger \\
-1463 \pm 63 \\
+534 \pm 42 \\
+760 \pm 69 \ddagger \\
-2005 \pm 88\end{array}$ \\
\hline
\end{tabular}

*All values are means $\pm S E$ ( $n=8$ in both groups).

$\dagger$ Maximum rate of increase in left ventricular pressure.

†Significantly different from control $(p<0.05)$.

\section{HISTOPATHOLOGY AND DETERMINATION OF}

\section{METALS}

Samples were excised from the kidney, heart, and arteries (thoracic and abdominal aorta, common carotids, and subclaviars) for examination by light microscopy. The cadmium, zinc, and copper contents of the kidneys and heart were determined by atomic absorption spectrophotometry, according to the methods of Sorenson et al, ${ }^{15}$ and Murthy and Petering. ${ }^{16}$ The concentration of the metals was referred to the wet weight of the organs.

\section{STATISTICAL ANALYSIS}

Values given are means $\pm S E$. The difference of paired mean values was analysed by the Dunnet $t$ test for multiple comparison ${ }^{17}$ and considered to be significant when $\mathrm{p}$ values were less than 0.05 .

\section{Results}

No difference in behaviour, growth rate, and final body weight was found in the two groups of rabbits. Systolic, diastolic BP, HR, and MOC were not affected by the treatment with cadmium. On the other hand, in the exposed animals AVR was increased, whereas dLVP/dt, ABF, SV, CO, LVMW, and SW were significantly reduced (table 2 ).

The exposed rabbits showed a decrease in the pressor response to vagotomy and no modifications in the pressor, chronotropic, and inotropic responses to BCO (table 3). The hypotensive and positive inotropic responses to isoprenaline (stimulating both $\beta_{1}$-and $\beta_{2}$-adrenoceptors) and serotonin were reduced by the treatment, whereas the hypertensive responses to angiotensin I and II were potentiated; furthermore, these two physiological agonists produced in the exposed group, respectively, a potentiation of the negative inotropic and chronotropic effects. The effects of histamine and acetylcholine were not modified by cadmium.

Tyramine (a drug exhibiting sympathomimetic effects by inducing a rapid and brief displacement of noradrenaline from axonal postganglionic adrenergic terminals) and hexamethonium (leading to sympathoand parasympathoplegic effects by blocking the transmission in autonomic ganglia) showed similar cardiovascular responses in the two groups of animals (table 4). Similarly, papaverine (a non-specific vascular 
Table 4 Cardiovascular changes after intravenous administration (iv) or intracarotid infusion (ici) of several drugs in control and male rabbits* that had been exposed to cadmium

\begin{tabular}{|c|c|c|c|c|c|c|}
\hline \multirow{4}{*}{$\begin{array}{l}\text { Tyramine }(1 \mathrm{mg} / \mathrm{kg}, \mathrm{iv}) \\
\text { Hexamethonium } \\
(2 \cdot 50 \mathrm{mg} / \mathrm{kg}, \mathrm{iv}) \\
\text { Clonidine }(20 \mu \mathrm{g} / \mathrm{kg} \text { ici }) \\
\text { Guanethidine }(0 \cdot 50 \mathrm{mg} / \mathrm{kg}, \mathrm{iv}) \\
\text { Papaverine }(1 \mathrm{mg} / \mathrm{kg}, \mathrm{iv}) \\
\text { Verapamil }(50 \mu \mathrm{g} / \mathrm{kg} \text { iv })\end{array}$} & \multicolumn{2}{|c|}{ Mean blood pressure } & \multicolumn{2}{|l|}{ Heart rate } & \multicolumn{2}{|l|}{$d L V P / d t \dagger$} \\
\hline & Control & $(\mathrm{mm} \mathrm{Hg})^{\text {Exposed }}$ & Control & $\begin{array}{c}\text { Exposed } \\
\text { (beats/min) }\end{array}$ & Control & $\begin{array}{l}\text { Exposed } \\
\text { g/sec })\end{array}$ \\
\hline & $+44 \pm 8$ & $+37 \pm 5$ & $+12 \pm 3$ & $+23 \pm 8$ & $+1423 \pm 201$ & $+1214 \pm 105$ \\
\hline & $\begin{array}{l}-21 \pm 2 \\
-15 \pm 3 \\
-30 \pm 4 \\
-21 \pm 3 \\
-20 \pm 5\end{array}$ & $\begin{array}{l}-15 \pm 4 \\
-10 \pm 2 \\
-12 \pm 2 \ddagger \\
-15 \pm 3 \\
-13 \pm 2\end{array}$ & $\begin{array}{l}-24 \pm 3 \\
-11 \pm 3 \\
-12 \pm 2 \\
+8 \pm 2 \\
-24 \pm 4\end{array}$ & $\begin{array}{l}-31 \pm 4 \\
-27 \pm 2 \ddagger \\
-16 \pm 3 \\
+13 \pm 4 \\
-27 \pm 8\end{array}$ & $\begin{array}{l}-700 \pm 57 \\
-830 \pm 68 \\
-967 \pm 48 \\
+1154 \pm 109 \\
-516 \pm 39\end{array}$ & $\begin{array}{l}-680 \pm 43 \\
-754 \pm 51 \\
-1171 \pm 115 \\
+1060 \pm 84 \\
-554 \pm 11\end{array}$ \\
\hline
\end{tabular}

*All values are means $\pm \mathrm{SE}$ ( $\mathrm{n}=8$ in both groups).

†Maximum rate of increase in left ventricular pressure.

$\ddagger$ Significantly different from control $(p<0.05)$.

smooth muscle relaxant) and verapamil (a calcium antagonist which inhibits both in cardiac and smooth muscle the slow calcium influx through receptor operating channels) produced similar effects in the treated and control animals. Clonidine (reducing the sympathetic tone, primarily by stimulating central presynaptic or postsynaptic $\alpha$-adrenoceptors, and enhancing vagal reflexes) was administered by intracarotid infusion to minimise its peripheral $\alpha$-adrenoceptor stimulating properties. Consequently, the intracarotid infusion of the drug induced arterial hypotension, bradycardia, and depressed cardiac inotropism all reached the maximal value after a 5-7 minute period of infusion. The exposed rabbits showed an increase in the clonidine induced bradycardia without modification of BP and inotropic responses. Guanethidine (depleting the stores of norepinephrine in the peripheral sympathetic nerves with possible transient sympathomimetic effects) did not induce an increase in BP in either treated or control groups. Moreover, the treated rabbits showed a decrease in the hypotensive response to the drug whereas the negative inotropic effects were not modified.

No alterations were found by light microscope examination of the kidney, heart and vessels of the treated rabbits.

The concentrations of cadmium was greatly augmented in the kidney of the exposed rabbits (table 5).

Table 5 Cadmium, zinc, and copper contents in kidneys and heart of control and cadmium exposed male rabbits*

\begin{tabular}{lcll}
\hline & \multicolumn{3}{l}{ Metals $(\mu \mathrm{g} / \mathrm{g})$} \\
\cline { 2 - 4 } & Cadmium & Zinc & Copper \\
\hline Kidney & $0.7 \pm 0.2$ & $22.7 \pm 1.3$ & $2.9 \pm 0.1$ \\
Control & $175.8 \pm 15.6 \dagger$ & $32.6 \pm 2.1 \dagger$ & $3.1 \pm 0.2$ \\
$\quad$ Exposed & $<0.03$ & $18.9 \pm 1.9$ & $3.9 \pm 0.4$ \\
Heart & $0.6 \pm 0.1 \dagger$ & $18.3 \pm 0.9$ & $3.8 \pm 0.8$ \\
$\quad$ Control & Exposed &
\end{tabular}

*All values are means $\pm \mathrm{SE}$ ( $\mathrm{n}=8$ in both groups).

+Significantly different from control $(\mathrm{p}<0.05)$.
The heart of the same animals showed a low but significant increase of the metal. Zinc was significantly higher in the kidney of the treated rabbits but unchanged in the heart. Copper concentrations of the examined organs were not altered by exposure to cadmium.

\section{Discussion}

Arterial hypertension has been induced in rabbits by intraperitoneal injections of cadmium acetate. ${ }^{18}$ In this investigation, however, BP and HR were not modified despite the increased AVR. This may b8 explained by the reduction of SV and $\mathrm{CO}$ related to the depressed myocardial contractility, as indicated by the decrease of $\mathrm{dLVP} / \mathrm{dt}, \mathrm{LVMW}$, and SW. The reduction of $\mathrm{ABF}$ in the exposed animals may thus be referred both to lower cardiac inotropism and arterial vasoconstriction.

Since the effects of BCO and hexamethonium were not modified by exposure to cadmium, the cardiovascular actions of the metal cannot be related to afferent and postganglionic efferent baroreflex components. The lack of a significant effect on centrally mediated sympathetic tone is shown not only by the unchanged cardiovascular responses after the ganglionic blockade by hexamethonium but also by the absence of differences in the hypotensive and negative inotropic responses to clonidine. On the other hand, vagal activity was affected by cadmium since the pressor responses to vagotomy were reduced. In this respect, the increased bradycardiac effect of clonidine $^{19}$ may be related to an increase in vagal tone induced by the exposure.

Since only the pressor but not the chronotropic and inotropic responses to vagotomy were modified by cadmium, it may be inferred that the increase of vagal tone induced by the metal is associated with hypofunction of the postganglionic sympathetic nerves reaching the vasculature. This conclusion is emphasised by the fact that guanethidine, a drug that does 
not cross the blood brain barrier and depletes the stores of neurotransmitter in the sympathetic endings, ${ }^{20}$ induced lower hypotensive responses in the treated rabbits. The tyramine sensitive mechanisms, however, inducing release of noradrenaline from the peripheral sympathetic terminals, ${ }^{21}$ did not appear to be influenced by exposure to cadmium.

The effects of cadmium on systemic haemodynamics do not seem to affect the papaverine and verapamil sensitive mechanisms, located in the cardiac and vascular myocells, that contribute to the regulation of the intracellular availability of calcium ions for the contractile systems. ${ }^{22}$ Nevertheless, cardiac contractility, HR, coronary flow rate, and A-V node conductivity have been found to be reduced both in vivo $^{23}$ and in the perfused heart of $\mathrm{Cd}$ exposed rats, ${ }^{24-26}$ and in the heart derived from other species $^{27}$; these effects were related to cadmium induced alterations of calcium mediated or calcium activated physiological and biochemical pathways, or both, probably through a competition of the metal with calcium for membrane and intracellular sites linked with the contractile systems. ${ }^{28}$ Moreover, cadmium decreased high energy phosphate concentrations in the isolated cardiac tissue. ${ }^{24-26}$ The depressed phosphorylation of the cardiac muscle, together with the centrally mediated vagal hyperactivity and postganglionic sympathetic hypofunction, may explain the reduced cardiac inotropism found in the present experiment.

In addition to the capacity of interacting with the neurogenic systems cadmium was active in modifying cardiac and vascular responsiveness to some receptor stimulating drugs. In the rabbits exposed to this element (as in rats $^{8}$ ) there was a potentiation of the $\beta_{1}$ - and $\beta_{2}$-adrenoceptor stimulating effects of isoprenaline at the level of myocardial and vascular smooth muscles. Furthermore, cadmium enhanced vasoconstriction after the stimulation with angiotensin I and II and opposed the serotonin induced vasodilatation and positive inotropism (these effects were not noted in $\mathrm{Cd}$ treated rats $^{8}$ ). The increased AVR may in part be related to modification in the activity of the kallikrein-kinin system that acts on the kidney and on the cardiovascular system. Reduced urinary kallikrein activity was found by our group in Cd treated rats, ${ }^{910}$ and in male New Zealand rabbits receiving $56 \mu \mathrm{g} / \mathrm{ml}$ of cadmium in drinking water for 90 days $^{29}$; unfortunately, in this preliminary research cardiovascular parameters were not determined. Neither the Cd treated rabbits nor the rats ${ }^{8}$ showed cardiovascular alterations after the stimulation of the peripheral histaminergic and muscarinic cholinergic receptors. In the present investigation, however, the stimulation of the vascular $\alpha$ adrenoceptors by phenylephrine, provided with predominant $\alpha_{1}$ adrenoceptor stimulating activity, was not reduced by exposure to cadmium, as was observed in Cd-treated rats. ${ }^{8}$ On the whole, the increased AVR may be related to cadmium induced alterations of cardiovascular mechanisms including those linked to angiotensin I and II, serotonin, and kinins.

The neurogenic, humoral, and effectorial mechanisms which may be modified by exposure to cadmium have been reviewed previously. ${ }^{8}$ Our results show that in the rabbit the effects of cadmium on the mechanisms regulating the heart and vasculature are independent and not integrated through significant baroflex relations. In this respect the increased AVR and the reduced myocardial contractility appear to act to preserve a haemodynamic equilibrium without modification of BP, HR, MOC, and cardiac work. It cannot be excluded that a haemodynamic condition similar to that observed in the rabbits treated with cadmium may be present also in people exposed to cadmium showing BP and other cardiovascular parameters in the normal range.

An absence of alterations in the kidney and the cardiovascular system, by observation with the light microscope, was also shown in other studies of animals exposed to cadmium. ${ }^{30}$ Nevertheless, the ultrastructure of the heart of rats with long term inhalation exposure to cadmium oxide fumes has been found to be modified. ${ }^{31}$

The renal cadmium content of the treated rabbits was higher than that generally observed in the normal populations but lower than the critical value estimated in workers exposed to the metal. ${ }^{32}$

We did not observe an increase of renal copper, as was found in cadmium treated rats. ${ }^{8-10}$ It seems likely that copper metabolism is less affected by cadmium in rabbits than in rats, or that the kidney of rabbits contains lower or different species, or both, of metallothionein, able to bind cadmium and other elements. $^{33}$

This study confirms previous reports which have shown that cadmium produces specific and multiple effect on the cardiovascular system; however, these actions produce both differences and similarities in rats and rabbits. For this reason, data obtained from experimental animals have to be cautiously extrapolated to people exposed to cadmium, taking into account that the effects of cadmium are influenced by several variables.

\section{References}

1 Friberg L, Piscator M, Nordberg GF, Kjellstrom T. Cadmium in the environment. 2nd ed. Cleveland: CRC Press Inc, 1974.

2 Lauwerys R, De Wals P. Environmental pollution by cadmium and mortality from renal diseases. Lancet 1981;i:383.

3 Voors AW, Johnson WD, Shuman MS. Additive statistical effects of cadmium and lead on heart-related disease in a North Carolina autopsy series. Arch Environ Health 1982;37:98-102. 
4 Nogawa K, Kawano S, Nishi M. Mortality study of inhabitants in a cadmium polluted area with special reference to lowmolecular weight proteinuria. In: Ernst WHO, ed. Proceedings of the international conference on heavy metals in the environment, Amsterdam, September, 1981. Edinburgh: CEP Consultants Ltd, 1983:538-40.

5 Schroeder HA. Cadmium as a factor in hypertension. J Chronic Dis 1965;18:647-56.

6 Staessen J, Bulpitt CJ, Roels H, et al. Urinary cadmium and lead concentrations and their relation to blood pressure in a population with low pressure. Br J Ind Med 1984;41:241-8.

7 Boscolo P, Bergamaschi A, Carelli G, Sperduto B, Finelli VN. Hypertension among workers in a plant for the primary production of zinc. In: Müller G, ed. Proceedings of the international conference on heavy metals in the environment, Heidelberg, September, 1983. Edinburgh: CEP Consultants Ltd, 1983:513-6.

8 Carmignani M, Boscolo P. Cardiovascular responsiveness to physiological agonists of male rats made hypertensive by longterm exposure to cadmium. Sci Total Environ 1984;34:19-33.

9 Boscolo P, Finelli VN, Choudhury H, Petering G. Kallikrein activity in urine of cadmium exposed rats in relation to the development of hypertension. In: Bolck F, ed. KadmiumSymposium, Jena, August 1977. Jena: Wissenschaftliche Beiträge der Friedrich Sciller-Universität, 1979:325-9.

10 Boscolo P, Porcelli G, Carmignani M, Finelli VN. Urinary kallikrein and hypertension in cadmium-exposed rats. Toxicol Lett 1981;7:189-94.

11 Neal JJ, Halpern W, Reeves TJ. Velocity and acceleration of pressure change in heart and arteries. J Appl Physiol 1960; 15:747-9.

12 Crawford WJ, Teamy RJ, Hawthorne EW. Increased myocardial contractility during the initial period of hypertension in dogs following renal artery constriction. Fed Proc 1973;32:351.

13 Davidson DM, Covell JW, Mallock CI, Ross JJ. Factors influencing indices of left ventricle contractility in the conscious dog. Cardiovasc Res 1974;8:299-312.

14 Carmignani M, Carelli G, Sacchettoni-Logroscino G, Gioia A, Boscolo P. Chronic exposure of rats to sodium arsenite or arsenate: cardiovascular function and tissue metal levels. In: Anke M, Baumann W, Bräunlich H, Brückner C, eds. 4. Spurenelement-Symposyum 1983, Jena, July, 1983. Jena: Wissenschaftliche Beiträge der Friedrich-Sciller-Universität, 1983:119-26.

15 Sorenson JRJ, Melby EG, Nord PJ, Petering HG. Interferences in the determination of metallic elements in human hair. Arch Environ Health 1973;27:36-9.

16 Murthy L, Petering HG. The effect of dietary zinc and copper interrelationships on blood parameters of the rat. J Agric Food Chem 1976;24:808-11.

17 Dunnet $\mathrm{CW}$. New tables for multiple comparison with a control. Biometrics 1964;3:482-7.

18 Thind GS, Karrema G, Stephan KF, Blakemore WS. Vascular reactivity and mechanical properties of normal and cadmium hypertensive rabbits. J Lab Clin Med 1970;76:560-8.

19 Kobinger W, Walland A. Facilitation of vagal reflex bradycardia by an injection of clonidine on central alpha-receptors. Eur $J$ Pharmacol 1972;19:210-7.

20 Scriabine A, Taylor DG. Antihypertensive drugs. In: Antonaccio MJ, ed. Cardiovascular pharmacology. New York: Raven Press, 1984:257-94.

21 Mayer SE. Drugs acting at synaptic and neuroeffectọr junctional sites. Neurohumoral transmission and the autonomic nervous system. In: Goodman Gilman A, Goodman LS, Gilman A, eds. Pharmacological basis of therapeutics, 6th ed. New York: MacMillan, 1980.

22 Itoh T, Kajiwara M, Kitamura K, Kurijama $\mathbf{H}$. Effects of vasodilator agents on smoother muscle cells of the coronary artery of the pig. Br J Pharmacol 1981;74:455-68.

23 Kopp SJ, Fischer VW, Erlanger M, Perry EF, Perry HM. Electrocardiographical, biochemical and morphological effects of chronic low level cadmium feeding on the rat heart. Proc Soc Exp Biol Med 1978;159:339-45.

24 Kopp SJ, Bárány M, Erlanger M, Perry EF, Perry HM. The influence of chronic low-level cadmium and or lead feeding on myocardial contractility related to phosphorylation of cardiac myofibrillar proteins. Toxicol Appl Pharmacol 1980;54:48-56.

25 Kopp SJ, Perry HM, Perry EF, Erlanger M. Cardiac physiologic and tissue metabolic changes following chronic low-level cadmium and cadmium plus lead ingestion in the rat. Toxicol Appl Pharmacol 1983;69:149-60.

26 Prentice RC, Hawley PL, Glonek T, Kopp SJ. Calciumdependent effects of cadmium on energy metabolism and function of perfused rat heart. Toxicol Appl Pharmacol 1984;75:198-210.

27 Pilati CF, Ewing KL, Paradise NF. Effects of cadmium on contractility and calcium concentration in isolated heart muscle. Proc Soc Exp Biol Med 1982;169:480-6.

28 Nasu T. Spasmolytic effect of cadmium and cadmium uptake in aorta. Br J Pharmacol 1983;79:751-4.

29 Boscolo P, Finelli VN, Choudhury H, Petering HG. Urinary esterase (kallikrein) activity in rat and rabbit exposed to cadis mium as related to hypertension. In: Annual report 1976-7 Center for the study of the human environment, USPHS ES 00159, Department of Environment Health. Ohio: University of Cincinnati, 1977:74-80.

30 Piscator M, Axelsson B. Serum proteins and kidney function after exposure to cadmium. Arch Environ Health 1970;21: 604-8.

31 Kolakowski J, Baranski B, Opalska B. Effect of long-term inhalation exposure to cadmium oxide fumes on cardiac muscle ultrastructure in rats. Toxicol Lett 1983;19:273-8.

32 Roels H, Lauwerys R, Dardenne AN. The critical level of cadmium in human renal cortex: a re-evaluation. Toxicol Lett 1983;15:357-60.

33 Cherian MG, Goyer RA. Metallothioneins and their role in the metabolism and toxicity of metals. Life Sci 1978;23:1-10.

\section{Destruction of manuscripts}

From 1 July 1985 articles submitted for publication will not be returned. Authors whose papers are rejected will be advised of the decision and the manuscripts will be kept under security for three months to deal with any inquiries and then destroyed. 